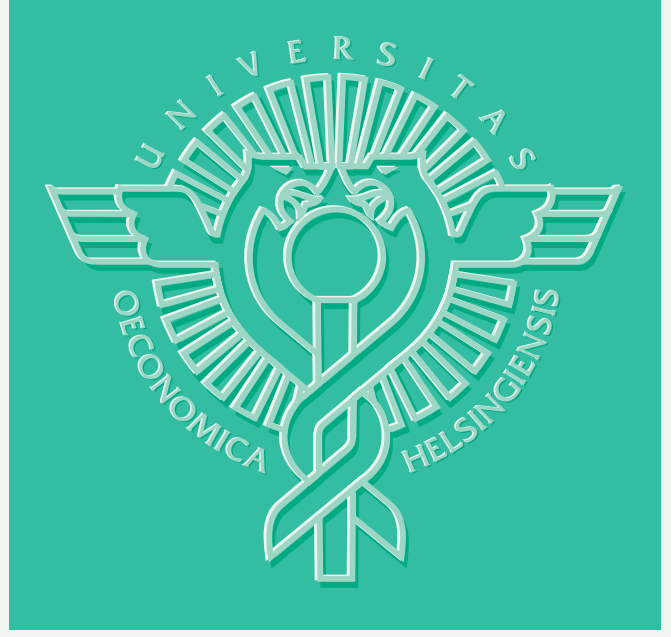

Elias Rantapuska

\title{
DO INVESTORS REINVEST DIVIDENDS AND TENDER OFFER PROCEEDS?
}


Elias Rantapuska

\title{
DO INVESTORS REINVEST DIVIDENDS AND TENDER OFFER PROCEEDS?
}

\author{
Finance \\ November \\ 2005
}


HELSINGIN KAUPPAKORKEAKOULU

HELSINKI SCHOOL OF ECONOMICS

PL 1210

FIN-00101 HELSINKI

FINLAND

(C) Elias Rantapuska and

Helsinki School of Economics

ISSN 1235-5674

ISBN 951-791-979-4 (Electronic working paper)

Helsinki School of Economics -

HSE Print 2005 


\title{
Do investors reinvest dividends and tender offer proceeds?
}

\author{
Elias Rantapuska* \\ Helsinki School of Economics and GSF
}

First draft: February 1, 2005

This version: November 18, 2005

\begin{abstract}
This study documents how much investors reinvest dividends and tender offer proceeds. I find that households reinvest only a small proportion of funds within two weeks, less than $1 \%$ of cashdividends and around $10 \%$ of tender offer proceeds. Tender offer proceeds are more likely to be reinvested, even when the investor and size of the cash flow are kept constant. This finding is consistent with the idea that investors have separate mental accounts for dividends and capital assets.
\end{abstract}

JEL-classification: G35, D12, G34

Keywords: Dividend reinvestment, dividend payment, self-control, mental accounting, tender offer

\footnotetext{
* Correspondence: Elias Rantapuska, Helsinki School of Economics, Department of Accounting and Finance, P.O. BOX 1210, Finland. Tel: +358-9-43138974, Fax: +358-9-43138678, Email: elias.rantapuska@hse.fi. I am most grateful to Matti Keloharju and Samuli Knüpfer for insightful discussions. I would also like to thank seminar participants at the Swedish School of Economics, Finnish Doctoral Programme in Economics, European Finance Association Moscow Meetings, Eric Deighton, Seppo Ikäheimo, Markku Kaustia, Mikko Niemenmaa, Bernt Arne Ødegaard, Hersh Shefrin, Scott Weisbenner, and Jouko Ylä-Liedenpohja for helpful comments and suggestions. Mikael Katajamäki provided excellent research assistance. Financial support from the Okobank Group Research Foundation, Finnish Foundation for Advancement of Securities Markets, Yrjö Uitto Foundation, Helsinki School of Economics Foundation, Wihuri Foundation, Graduate School of Finance, and the Academy of Finland is gratefully acknowledged. Finally, the author wishes to thank Barclays Global Investors for the Best Doctoral Paper Award at the EFA Moscow Meetings.
} 


\section{Introduction}

"The Microsoft payment, which affected 4.6 million shareholders, was nearly as large as the \$38 billion federal income-tax rebate paid in the summer of 2001. But unlike the rebate, which many Americans spent, economists said the dividend will have a smaller impact on spending because much of it will be reinvested in stocks or left in brokerage accounts."

Wall Street Journal

February 1, 2005

In 1999, US firms alone paid USD 222 billion in cash dividends (Grullon and Ikenberry 2000; Grullon and Michaely, 2002). While there has been a lot of research on why dividends are paid at all and how dividend policies are determined (for a review, see Allen and Michaely, 2004), very little is known about what happened to the 222 billion dollars cash in dividends after they left corporate treasuries. Some of it could have been reinvested, yet how much and by which investors are open questions.

Dividends are not the only flows from firms to investors which may be reinvested. Investors also receive substantial sums of cash when they sell shares to a bidder in a tender offer. In a sale resulting from a tender offer, the whole position is liquidated at once and for good, whereas in the case of a dividend payment, only a small fraction of corporate assets is typically distributed to shareholders. Despite the differences, these two liquidations of equity share an important common characteristic. Unless an investor holds a controlling interest in the company, the cash disbursement is exogenous.

After payments of dividends or tender offer proceeds, investors must decide whether to reinvest the funds in the financial market. For an individual investor, the obvious alternative is consumption. However, the source of income may make a difference in the decision between consuming versus reinvesting, especially in the case of individual investors. Dividends and proceeds from tender offers may be in different mental accounts: dividends are generally regarded as income, an annual cash flow to be used for consumption (Shefrin and Statman, 1984). In contrast, when forced to sell stocks, an investor may feel guilty about consuming the proceeds instead of reinvesting. Likewise, foundations and endowments often have rules forcing expenses and donations to be covered by dividends rather than proceeds from the sale of securities.

Earlier literature on the psychology of dividends lacks systematic empirical evidence on investor behavior. The purpose of this study is to fill this gap and contribute to the discussion on 
payout policy. I do this by answering two questions. First, are dividends and tender offer proceeds reinvested in the stock market? Second, do investors treat them differently? The opening quotation hints that investors reinvested much of the dividends paid by Microsoft, but research has not yet shown whether dividends are reinvested at all, let alone how much of them is reinvested.

There are four reasons why Finland is an exceptionally good test-laboratory for studying reinvestment of dividends and tender offer proceeds. First, high-quality daily data on all trades by every market participant facilitates a detailed analysis of what investors do with dividends and the tender offer proceeds they receive. The data allow identifying, on a daily basis, which domestic investors receive dividends and tender offer proceeds and how they trade after having received these cash flows. Second, the strict rules of the Finnish Central Securities Depositary (FCSD) and electronic transfer of funds guarantee that dividends and tender offer proceeds are paid to investors within one trading day. As a result, the exact day that an investor has access to the funds can be identified. Third, dividends are paid only once a year rather than quarterly, which means that, on average, they are larger and transaction costs are less of an issue than in countries such as the United States, where dividends are paid quarterly. Fourth, dividend reinvestment plans are unknown in Finland. This ensures that the observed reinvestments are self-initiated rather than automatic.

I document evidence that the proportion of dividends and tender offer proceeds reinvested in the stock market is rather small. My analyses show that households reinvest probably less than $1 \%$ of the dividends within two weeks of the payment, and under no circumstances do they reinvest more than $8.1 \%$. Neither do institutions other than mutual funds reinvest. There is also strong evidence that investors are more likely to reinvest proceeds from tender offers than dividends. This result holds even when I control for the identity of the investor, the size of the cash flow, and the extraordinary nature of tender offer proceeds payment. This result can be understood in terms of mental accounting: investors label corporate cash disbursements to mental accounts of capital assets and dividend income, and tend more to reinvest the former.

The remainder of this paper is organized as follows. The next section reviews literature on the psychology of dividends and develops a testable hypothesis. Section 3 explains the relevant data features and institutional details of dividend payments and tender offers in Finland. Section 4 presents descriptive statistics on reinvestment activity and empirical evidence on the determinants of reinvestment decision. Section 5 concludes and discusses the implications of the findings. 


\section{The psychology of dividends}

When individual investors receive dividends or proceeds from a tender offer, they face a choice of either reinvesting or consuming; they are, in essence, making a saving decision. Focusing on this decision entwines this study with the literature on saving, and the research hypothesis is drawn from theory on the psychology of saving.

The literature on household saving has traditionally relied on the assumption of rational agents maximizing their lifetime utility by consumption smoothing. The life-cycle model of consumption was first formally derived in Modigliani and Brunberg (1954), who state that the young should borrow against their future income, the middle-aged save for retirement, and the elderly dissave their wealth. Although the life-cycle model has been enriched by adding components such as uncertainty, liquidity constraints, and habits, reconciling the empirical evidence with the idea of intertemporal consumption optimization has not been particularly successful. As Browning and Lusardi (1996, p. 1850) put it in a survey on household saving, "more problems remain than have been satisfactorily answered."

Although criticizing the assumptions of neoclassical economic theory is hardly a novel idea, proponents of behavioral economics argue that this is exactly what must be done to truly understand the saving behavior of households. Thaler (1990, 1994, 1999) argues that the behavioral concepts of self-control and mental accounting are necessary to capture the essence of a household saving decision. Recently, a number of other scholars have accepted the notion that it is essential to take into account behavioral factors to fully understand all aspects of the empirical data in studies on saving (Levin 1998; Bernheim, Skinner, and Weinberg, 2001; Gross and Souleles, 2002).

Introducing the concept of mental accounting enables the assumption that the labeling of cash flows may influence investor behavior. The key ingredient of this argument is that wealth is nonfungible. Home equity, stockholdings, money in savings account, and current income are in separate mental accounts (Thaler 1990, 1999) and spent accordingly, in contrast to the life-cycle theory assumption that wealth is perfectly fungible. An exemplifying implication of this argument is that an unexpected bequest of EUR 1,000 in the form of a securities portfolio has virtually no impact on consumption, whereas a bequest of the same size in cash is almost always consumed outright. The relevance of mental accounting also extends to issues beyond consumption and saving. Shefrin and Statman (1985), Odean (1998), Haigh and List (2005), and Kaustia (2005) argue that mental accounting influences investor trading behavior in the equity market. 
Why do people have separate mental accounts rather than pooling all wealth as a neoclassical agent would do? Some authors suggest that the main reason for this is a lack of selfcontrol. People may agree that they should save more, but they lack the willpower and fail to behave as predicted by the life-cycle theory. Shefrin and Statman (1984) argue that dividends, despite bearing a higher tax burden, offer a convenient solution to combat self-control problems. Individuals want dividends because establishing a rule of consuming dividends but leaving capital intact helps to control consumption. This argument is formalized in the behavioral lifecycle (BLC) model of Shefrin and Thaler (1988), who borrow the notion of an internal conflict from their related work in Thaler and Shefrin (1981). Instead of solving a problem of optimal consumption over a lifetime, the economic agent must first solve an internal one of being exposed to constant temptation to consume.

Shefrin and Thaler (1988) suggest that to cut excess spending, individuals create mental accounts for themselves with predefined, unambiguous rules of consumption, such as "consume dividends and never touch the principal." Saving dividends on a case by case basis without a predefined rule will not work, because the human will is weak and the psychic cost of using willpower is greater than the increased utility from more optimal consumption in the future. Not touching the principal is formalized by assuming a psychic cost, or guilt, for liquidations from the asset account.

However, it is justified to ask whether there is a penalty for invading the asset account and thus not reinvesting the proceeds from a liquidation of tendered shares when the liquidation is forced rather than self-initiated. The argument here is that in a tender offer, just as in the case of dividends, liquidation of holdings is externally initiated.

There are thus two forces driving the decision to reinvest: mental accounting and externality of the decision. Whichever of these dominates is a matter of empirical investigation. If an external decision to liquidate holdings removes the psychic cost of invading the asset account, I would expect there to be no difference in the propensity to reinvest. However, if there is a psychic penalty for invading the asset account, even in the case of an external decision, I would expect that the propensity to reinvest tender offer proceeds is greater than the propensity to reinvest dividends, ceteris paribus.

It is important to note that the BLC model is at odds with the assumptions, but not with all the predictions of the rational life-cycle model. It is possible that economic agents exhibit behavior consistent with both rational and behavioral life-cycle models. Hence, even if there is 
evidence in favor of the BLC model, this does not imply complete rejection of the rational lifecycle model.

\section{Data and institutional setting}

In this section, I review relevant institutional details of the dividend payment process, lag between last cum-dividend and payment date, and tender offers in Finland.

\subsection{Data}

The bulk of the data come from the Finnish Central Securities Depositary (FCSD), which maintains an electronic and official register of all securities transactions in Finland for virtually all companies listed on the Helsinki Exchanges (HEX, nowadays a part of OMX Group, Plc). The data comprise daily trading account records of all Finnish investors. The sample period runs from January 1, 1995 through November 28, 2002, a period that includes both bull and bear markets. More detailed information on the data can be found in Grinblatt and Keloharju (2000).

All transactions are tagged with a unique investor identification number enabling computation of the portfolio value, the position in every stock, and the value of trades for each domestic investor in the entire market on every day. Trades are aggregated at investor level by summing up the signed value of all buys and sells in the open market during the same trading day. Hence, the unit of observation is the net daily flow to the stock market by a single investor.

I group investors into the following six investor categories: nonfinancial firms, financial corporations, mutual funds, nonprofit organizations, households, and foreigners. This grouping is consistent with Grinblatt and Keloharju (2001), except that it treats mutual funds as a separate category and pools the general government category with other nonprofit organizations.

Foreigners trading in the Finnish stock market have the option of registering their stockholdings in their own name or via a domestic financial institution using a nominee account. It is impossible to perform an investor level analysis on foreign investors not registered under their own names, as their trades appear in the data under the name of the nominee institution with a separate flag for a nominee account trade. As all my subsequent analyses are at the investor level, I use data only from registered foreigners.

The FCSD data on securities transactions are supplemented with dividend and stock price data from HEX. There are 926 dividend payments by Finnish-listed companies during the sample period. There are no investor level data available for ten dividend events because five companies 
joined the FCSD electronic registry after the beginning of the sample period. The final sample hence consists of 916 dividend payments, and depending on the year, the data represent $97-100 \%$ of the total market capitalization.

\subsection{Payment systems in Finland}

Finnish interbank and retail payment systems are among the most highly sophisticated and efficient in the world (Iivarinen, 2002). All domestic banks and foreign bank branches executing fund transfers are members of two fully automated interbank payment systems. Small interbank payments are settled twice a day, and depending on the method of wiring (i.e., order of transfer on paper versus electronic order through the Internet), the payment is normally in the receiver's account within zero to two days. Checks are very rare and make up less than $0.1 \%$ of all payments.

\subsection{Dividend payment process in Finland}

In Finland, cash dividends are paid once a year, typically at the end of March or at the beginning of April. None of the listed corporations had a dividend reinvestment plan, although they are not explicitly prohibited by Finnish law.

The electronic ownership records of the FCSD determine to whom the dividends are paid. A shareholder does not have to do anything to receive the dividend; the company transfers the funds directly to the investor's bank account. An investor who has bought shares no later than on the last cum-dividend day $(t+0)$ is entitled to a dividend. Because of a settlement lag, ownership of shares is determined by the ownership records on the registration day, which is the third trading day after the last cum-dividend day $(t+3)$. The FCSD has strict rules for the payment of dividends; these rules guarantee that the bank accounts of shareholders are credited on the reported dividend payment day.

There is one exceptional situation in which a shareholder with a right to the dividend has no access to the funds on the payment day. This exception occurs when the settlement of shares is delayed on a trade that took place prior to the ex-dividend day and should have been settled within the conventional three-day settlement lag. Hence, if an investor buys shares on the last cum-dividend day and the settlement of shares is delayed until $t+4$ or later, the investor is not paid on the reported dividend payment day. In this case, the dividend is manually corrected by the FCSD and paid to the buyer with delay. 
According to the FCSD, manual corrections are a function of trading activity and account for only a small fraction of the dividend payments. As an example, Nokia (the most traded stock on HEX) had approximately 25,000 shareholders when dividends for fiscal year 1996 were paid. For this dividend payment, there were 84 manual payment corrections, causing a delay to less than $0.4 \%$ of the shareholders. As the number of corrections is relatively small, delayed payments are not an issue.

\subsection{Lag between last cum-dividend and payment day}

Compared with the United States, where dividends are paid several months after the ex-day, the lag between ex-day and payment day in Finland is relatively short, only a few weeks. Given this institutional feature, it is important to differentiate between trades related to ex-dividend day trading and reinvestment of dividends. To make sure that the ex-day trading related transactions do not confuse the analysis of reinvestment, I next investigate the length of the lag between the last cum-dividend day and payment day.

During the sample period, the FCSD did not regulate the day of dividend payment, but most companies followed the stock exchange norm of setting the payment day for the fifth trading day $(t+8)$ following the registration day $(t+3)$. This observation is confirmed in Table 1 and Figure 1 in which I calculate the lag between the last cum-dividend day and the payment day for all 916 dividend payments in the sample. Figure 1 peaks at the lag of 8 trading days, which is also the sample median. There are eight cases where a company had a lag of fewer than three trading days. These are companies that joined the FCSD register prior to their initial public offering (IPO) and paid dividends for previous fiscal year to pre-IPO shareholders.

Is the median lag of eight days sufficiently long to avoid confusion between trades related to reinvestment of dividends and trades related to ex-day tax arbitrage? By utilizing the same data as in this study, Rantapuska (2005, Fig. 3.) shows that the majority of short-term ex-day trades are concentrated on the last cum-dividend and the first ex-dividend day, rather than within a broader event window. In fact, the study shows that the number of short-term trades starts to rise five days before the last cum-dividend day, and the number returns to the same level five days after the last cum-dividend day, at $t+5$. Given the median of eight days between the last cum-dividend day and the payment day, trades related to ex-dividend day trading are unlikely to affect the analysis on reinvestment activity. 
Table 1

Distribution of lag between last cum-dividend and payment day, trading days

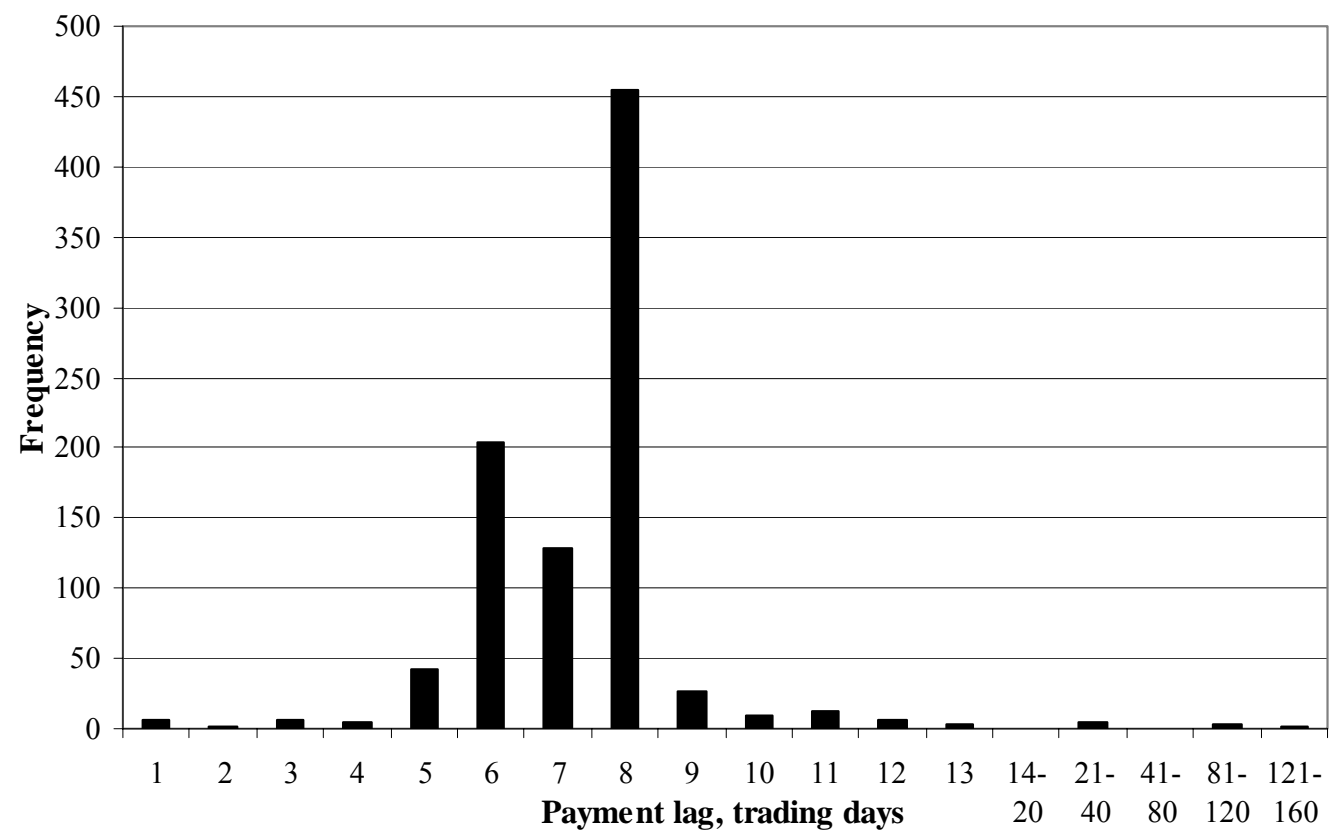

Fig. 1. Distribution of lag between last cum-dividend and dividend payment day

\subsection{Rules for a tender offer}

The rules for a tender offer in Finland differ from those in the United States in the following way. First, two-tier offers promising a higher return for tendering shareholders are not allowed. Second, the governing rules depend on the fraction of shares owned by the bidder. If the bidder owns less than two-thirds of the shares outstanding, she is free to make offers for any number of shares at any price. If the bidder owns more than two-thirds, she is by law obliged to make an offer for the remaining shares outside her control. Finally, if the ownership exceeds $90 \%$, the 
bidder also has to make a demand for all outstanding shares held by minority investors. However, she also has the right to compulsory acquisition of any shares not tendered at this stage. ${ }^{1}$

Earlier empirical evidence from the same market (Karhunen, 2002) shows that in almost all takeovers, the bidder is successful in acquiring full control and tendering is thus only a matter of time. Based on this evidence, payments of tender offer proceeds are assumed to be exogenous throughout this study. In other words, I assume that investors do not choose to exchange their holdings for cash, but tender because they have to.

\subsection{Cash disbursement from a tender offer}

After an investor has accepted a tender offer, the tendered shares are not sold instantly. Instead, the shares remain in the investor's account until the end of the offer period and cannot be transferred to any party other than the bidder. After the offer period is over, the bidder executes trades via the HEX trading system and acquires control of the tendered shares. Cash from the sale of shares is available to the investor on the settlement date. Because this study concentrates on cash disbursements that are exogenously initiated, rather than self-initiated, shares sold in the open market during the tender offer period are excluded from the analysis. ${ }^{2}$

\section{Empirical results}

\subsection{Descriptive statistics}

There were 916 cash dividend distributions between 1995 and 2002 by companies that are members of the FCSD registry. The vast majority of dividends are paid in the spring, as shown in Panel A of Figure 2. Panel B in the same figure shows that the total value of dividends paid increased significantly during the sample period. The upward trend is due to an increase in the number of listed companies, rising profits, and a higher propensity to distribute net profits as dividends. Panel B also shows that the flow of dividends to foreign shareholders increased significantly during the sample period, reflecting the growth of foreign ownership from $33 \%$ in 1995 to $67 \%$ in 2002.

\footnotetext{
${ }^{1}$ Although the bidder has a right to any remaining shares held by the minority, the Finnish corporate law allows dissenting shareholders not to surrender their shares without litigation. An arbitrator appointed by the Central Chamber of Commerce sets the price for the shares, which may be higher than the offer price. See Karhunen (2002) for further institutional details.

${ }^{2}$ I make one exception, the second offer for the shares of Hartwall. In this offer, the bidder bought shares in the open market for a price that was higher than in the tender offer. Because of the higher price, the majority of investors sold their shares in the open market instead of tendering.
} 
Panel A: Monthly distribution of dividends paid

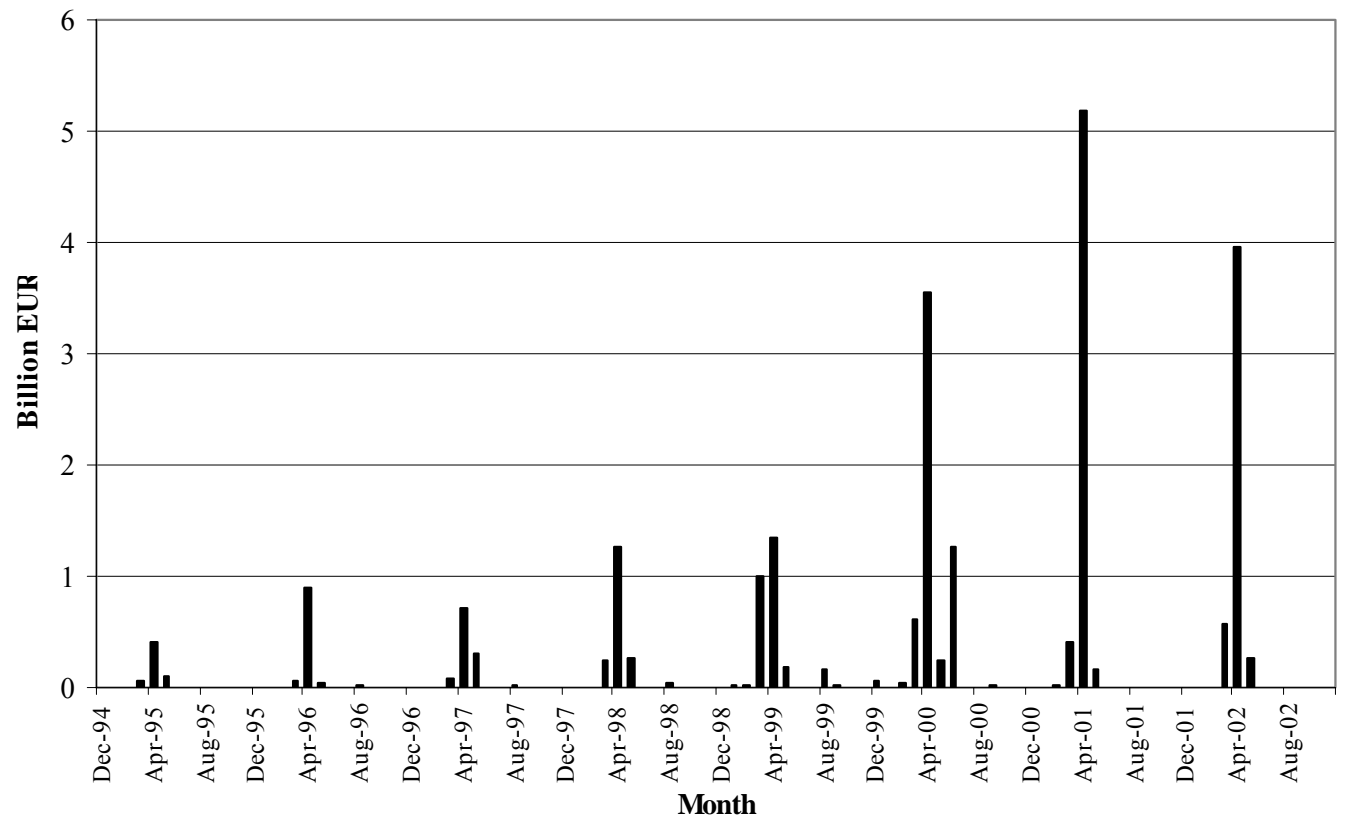

Panel B: Annual value of dividends received by investor category

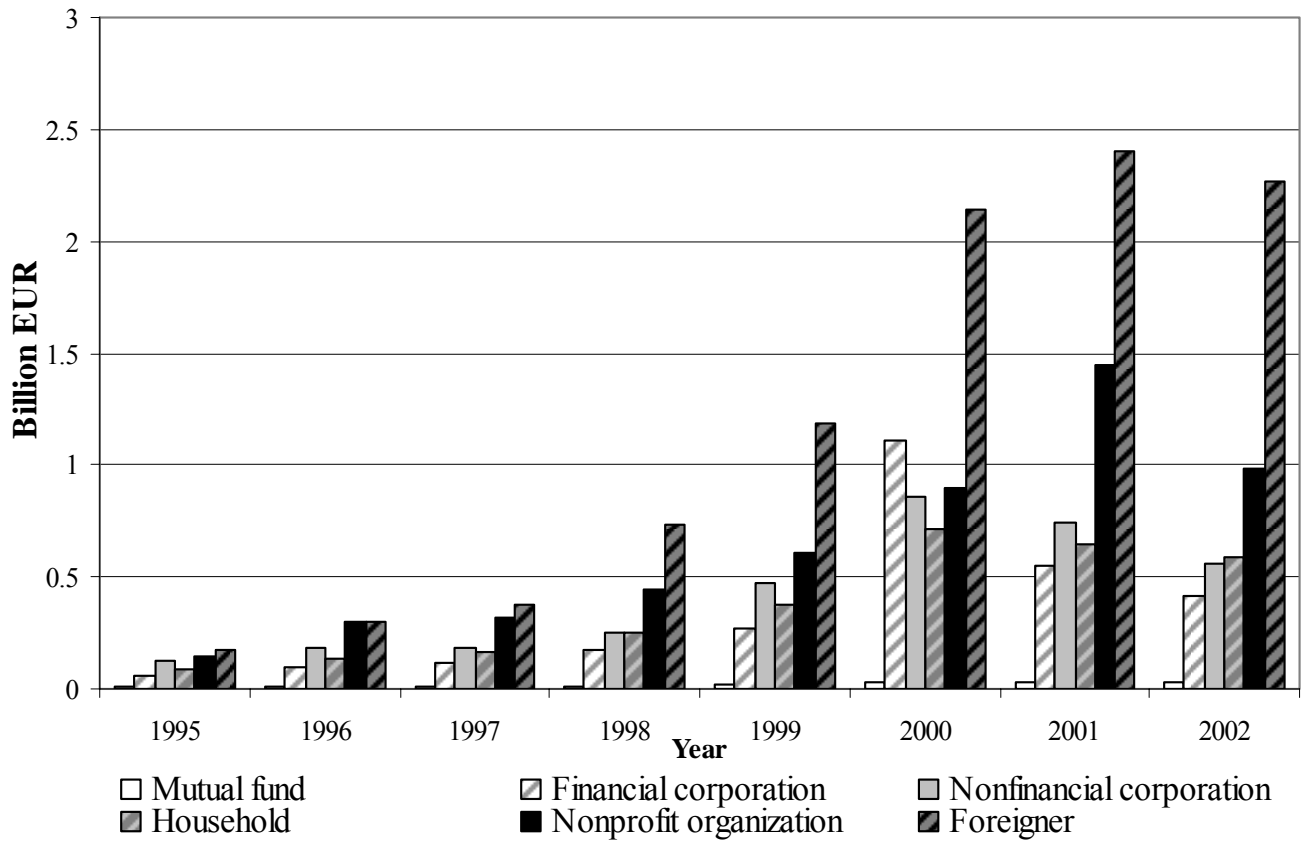

Fig. 2. Descriptive statistics on dividend payments. Panel A shows the gross value of cash dividends paid on each month of the sample period. Panel B shows the distribution of dividends received by investor category. The data include 8,861,622 cash dividend payments to domestic and foreign (registered and unregistered) shareholders. 
Table 2

Descriptive statistics on the full sample of dividends and tender offer proceeds

The table shows the distribution of dividend and tender offer proceed payments in the full sample of 916 dividend payments and 44 tender offers. Reported minimum, maximum, mean, and median values are in EUR. Statistics for the category foreigner are based on registered foreigners only. MDIV is a measure of the minimum amount of cash required to make a direct investment in the stock market and is defined in Section 4.1.

\begin{tabular}{|c|c|c|c|c|c|c|c|c|}
\hline Investor category & Minimum & Maximum & Mean & Median & $\begin{array}{c}\text { Std. } \\
\text { deviation }\end{array}$ & $\begin{array}{c}\text { Skew- } \\
\text { ness }\end{array}$ & Kurtosis & $\mathrm{N}$ \\
\hline
\end{tabular}

Full sample

\begin{tabular}{|c|c|c|c|c|c|c|c|c|}
\hline Panel A: Dividends & & & & & & & & \\
\hline Nonfinancial corporation & 0.01 & $66,302,556$ & 14,079 & 235 & 381,784 & 84 & 9,702 & 193,726 \\
\hline Financial corporation & 0.07 & $80,366,048$ & 107,040 & 2,960 & $1,389,863$ & 35 & 1,522 & 23,834 \\
\hline Mutual fund & 2.17 & 668,800 & 21,387 & 7,380 & 42,298 & 5 & 46 & 6,391 \\
\hline Nonprofit organization & 0.03 & $155,531,104$ & 46,618 & 1,473 & $1,083,918$ & 89 & 10,540 & 85,488 \\
\hline Household & 0.01 & $13,281,246$ & 579 & 76 & 13,751 & 495 & 376,700 & $3,049,410$ \\
\hline Foreigner & 0.07 & $31,558,502$ & 13,486 & 183 & 290,653 & 74 & 7,151 & 21,434 \\
\hline Total & & & & & & & & $3,380,283$ \\
\hline Panel B: Tender offers & & & & & & & & \\
\hline Nonfinancial corporation & 0.50 & $424,585,049$ & 466,860 & 3,328 & $10,000,679$ & 33 & 1,234 & 2,922 \\
\hline Financial corporation & 0.07 & $41,580,000$ & 611,157 & 6,328 & $2,990,456$ & 9 & 98 & 574 \\
\hline Mutual fund & $7,381.42$ & $4,647,600$ & 607,807 & 260,334 & 974,627 & 3 & 7 & 57 \\
\hline Nonprofit organization & 10.33 & $75,946,608$ & 359,248 & 11,446 & $3,016,192$ & 17 & 358 & 1,751 \\
\hline Household & 0.88 & $162,257,480$ & 18,372 & 1,602 & 795,990 & 147 & 27,885 & 63,431 \\
\hline Foreigner & 17.60 & $2,459,120,670$ & $4,737,364$ & 2,737 & $102,656,144$ & 24 & 571 & 576 \\
\hline Total & & & & & & & & 69,311 \\
\hline
\end{tabular}

Sample of cash flows greater than MDIV

\begin{tabular}{|c|c|c|c|c|c|c|c|c|}
\hline \multicolumn{9}{|l|}{ Panel C: Dividends } \\
\hline Nonfinancial corporation & 900.00 & $66,302,556$ & 71,368 & 4,318 & 864,648 & 37 & 1,890 & 37,566 \\
\hline Financial corporation & 900.00 & $80,366,048$ & 188,364 & 19,000 & $1,841,249$ & 27 & 865 & 13,520 \\
\hline Mutual fund & 900.00 & 668,800 & 26,677 & 11,400 & 45,940 & 5 & 39 & 5,087 \\
\hline Nonprofit organization & 900.00 & $155,531,104$ & 94,691 & 6,300 & $1,547,837$ & 63 & 5,169 & 41,844 \\
\hline Household & 900.00 & $13,281,246$ & 6,964 & 2,599 & 55,808 & 123 & 23,137 & 182,526 \\
\hline Foreigner & 900.00 & $31,558,502$ & 79,645 & 3,921 & 708,569 & 30 & 1,204 & 3,570 \\
\hline Total & & & & & & & & 284,113 \\
\hline \multicolumn{9}{|l|}{ Panel D: Tender offers } \\
\hline Nonfinancial corporation & 900.00 & $424,585,049$ & 668,777 & 7,719 & $11,967,091$ & 27 & 861 & 2,039 \\
\hline Financial corporation & 949.00 & $41,580,000$ & 865,972 & 32,550 & $3,530,252$ & 8 & 69 & 405 \\
\hline Mutual fund & 7,381 & $4,647,600$ & 607,807 & 260,334 & 974,627 & 3 & 7 & 57 \\
\hline Nonprofit organization & 1,127 & $75,946,608$ & 437,260 & 19,545 & $3,323,387$ & 15 & 294 & 1,438 \\
\hline Household & 900.00 & $162,257,480$ & 34,179 & 4,302 & $1,094,321$ & 107 & 14,754 & 33,546 \\
\hline Foreigner & 900.00 & $2,459,120,670$ & $7,068,940$ & 5,862 & $125,389,283$ & 20 & 383 & 386 \\
\hline Total & & & & & & & & 37,871 \\
\hline
\end{tabular}


Altogether, there are 8,861,622 dividend payments to domestic shareholders and registered foreigners. I narrow down the sample for two reasons. First, very passive investors are not particularly interesting. Hence, I first filter out completely inactive 'buy and hold' investors who did not trade at all in the calendar year during which they received a dividend. This leaves a sample of 3,380,283 dividend payments. Second, dividends paid to the same investor on the same trading day are aggregated. This further reduces the sample to 2,857,221 observations.

For the sample of tender offer proceeds, I select cash disbursements from offers in which there was a cash payment to investors tendering voluntarily. Following this criterion, I include cash disbursements from offers in which an investor could choose between cash and shares as well as from offers in which the investor had no other option than cash. However, I exclude compulsory acquisitions of stock that were preceded by a stock swap tender offer with no option for cash. Altogether, there are 44 tender offers qualifying for the sample. As in the case of dividend payments, I perform daily aggregation, remove inactive investors, and end up with 29,029 observations for tender offer proceeds.

The majority of dividend payments are rather small, as illustrated in Panel A of Table 2. For the purposes of subsequent analyses, I construct a subsample of dividends and tender offer proceeds which are large enough to be invested as such. To this end, I calculate for each sample year a measure of minimum direct investible value, MDIV. This measure indicates how much cash in hand an investor has to have to be able to make the smallest possible direct investment in a listed company. To compute the MDIV for each sample year, I first multiply lot size by close price on the first trading day of the year for all listed shares. Finally, I use the median of these values at the beginning of the year. The MDIV has a median of EUR 1,724 and varies from EUR 900 to EUR 3,835. Descriptive statistics for the sample of dividends and tender offer proceeds exceeding the MDIV are reported in Panels C and D of Table 2.

\subsection{Unconditional reinvestment ratios}

The most obvious way to measure the degree of cash flow reinvestment is to divide net investment in the stock market by the value of cash disbursement. Two major shortcomings make this simple measure rather unpractical for the purposes of this study. First, many investors do not reinvest after a cash disbursement but sell instead. This often makes the aggregate reinvestment ratio negative, which is hardly an equilibrium outcome. Second, the reinvestment measure varies considerably, making extreme values difficult to interpret. For example, if an investor receives a 
EUR 10 dividend and subsequently invests EUR 50,000 in the stock market, it is debatable whether this should be considered a 5,000\% reinvestment.

To overcome these two problems, I measure reinvestment activity by computing two slightly modified ratios. First, I assume that the reinvestment ratio of an investor is bounded by zero and one, inclusive. Hence, a negative net investment in the stock market after a corporate cash disbursement is considered as a zero reinvestment. Defining the variable to be between zero and one is consistent with Grinblatt and Keloharju (2004), who use the same range for measuring the amount of repurchase activity associated with wash sales around the turn of the year. However, disallowing negative values causes this reinvestment ratio to be upward biased and positively related to the degree of trading activity, and both factors must be accounted for when interpreting the results. For example, an investor who has a $50 \%$ probability of buying and a $50 \%$ probability of selling stocks on any given day has a $50 \%$ probability of having a strictly positive reinvestment ratio on any given day. Correspondingly, an investor with a $10 \%$ probability of both buying and selling has a one out of ten chance of having a strictly positive reinvestment ratio.

Second, I introduce a symmetric reinvestment ratio by bounding the reinvestment ratio within the range of $[-1,1]$. If, on aggregate, there is no reinvestment by a given investor category, the second ratio will reflect this by being close to zero. In addition, this measure does not suffer from the bias caused by differences in trading activity.

I introduce two different lags for reinvestment and compute the value reinvested on the day of cash disbursement and over a period of ten subsequent days. As will be shown in Section 4.4., after ten days the link between corporate cash disbursements and investor trading fades away. Throughout this paper, I define reinvestment as the net flow to the entire stock market rather than to individual shares.

Computing reinvestment ratios on the day of payment is straightforward. However, when I allow a 10-day period for reinvestment, net investment in the stock market cannot be simply divided by the value of cash disbursement. This is because most dividend payments are clustered, causing observations to be nonindependent. To account for the clustering, I aggregate all dividends or tender offer proceeds which are paid within ten trading days of one another and received by the same investor. Furthermore, I assume that the reinvestment period begins on the day of the last dividend payment and ends on the tenth trading day following the last payment. This is equivalent to assuming that investors wait until the last clustered dividend before they start reinvesting. For example, if an investor receives a dividend on trading days $t, t+6, t+12$, and $t+54$, dividends paid on days $t, t+6$, and $t+12$ are aggregated into a single observation, 
and the reinvestment period is assumed to run from trading day $t+12$ to trading day $t+22$. Correspondingly, the dividend on day $t+54$ is treated as a single observation with a reinvestment period from $t+54$ to $t+64$. If payment of tender offer proceeds enters the dividend clustering or reinvestment period (or vice versa) of an investor, both observations are excluded from the sample. In terms of the previous example, if the investor receives proceeds from a tender offer on any trading day between $t-10$ and $t+22$ or between $t+44$ and $t+64$, the overlapping observations are discarded. Similarly, in the 1-day specification, I exclude all observations in which both types of cash flows are paid to the same investor on the same trading day.

Another possible way to perform the aggregation is to assume that the investor starts reinvesting as soon as the first dividend is paid. In the previous example, this would mean that the investor starts to reinvest the clustered dividend on trading day $t$ instead of trading day $t+12$. The truth is probably somewhere between these two methods of aggregation: some investors may choose to invest every dividend separately, while others probably always wait until the last dividend before they start reinvesting. I also re-estimate the results in Tables 3, 4, and 6 by assuming that the investors start reinvesting as soon as they receive the first cash flow. The results are qualitatively insensitive to the method of aggregation, and available upon request from the author.

Investors receiving dividends could be systematically different from those who receive tender offer proceeds. To account for this potential difference, I compare the reinvestment ratios of investors who received both payments. For this comparison, I first calculate the average tender offer proceeds reinvestment ratio for each investor and then compute the average dividend reinvestment ratio for that same investor. Finally, I compute average unconditional reinvestment ratios for all six investor categories and for the two reinvestment periods. These results are reported in Table 3.

Panel A in Table 3 reveals that the average reinvestment ratios are very close to zero. Households reinvest less than $1 \%$ of dividends and this point estimate climbs to only $4.4 \%$ when I use the more aggressive measure $[0,1]$ and a 10-day reinvestment period. Mutual funds have the highest propensity to reinvest, and depending on the measure, they reinvest up to $39 \%$ of dividends within two weeks of payment. While this finding may be driven by small sample size, a possible explanation is that mutual funds have target cash positions and they promptly return excess funds from dividends to the stock market. 
Table 3

Unconditional reinvestment ratios

This table reports reinvestment ratios for all investors in the sample who received both dividends and proceeds from tender offers. The reinvestment ratio is defined as Net flow to the stock market/Value of corporate cash disbursement. In the leftmost columns, the reinvestment ratio has a range of [0,1], and a value of 0 (1) is assigned if the ratio is below (above) zero (one). Correspondingly, the ratio has a range of $[-1,1]$ in the rightmost columns. Reinvestment ratios are calculated by first computing the average reinvestment ratio for each investor and then averaging over each investor category. The 10-day reinvestment ratio is calculated by aggregating to a single observation all cash disbursements of the same type clustered within ten days of one another. When cash disbursements are aggregated, net flow to the stock market for the subsequent ten days is calculated from the day of the last dividend payment to the $10^{\text {th }}$ day after the last dividend payment. The MDIV is defined in Section 4.1 , and corresponds to the minimum value of funds required to make a direct investment in the stock market. The number of observations in the 10-day window is smaller because of a smaller number of independent observations.

\begin{tabular}{|c|c|c|c|c|c|c|c|c|c|c|c|c|}
\hline \multirow{3}{*}{$\begin{array}{l}\text { Period } \\
\text { Type of cash flow }\end{array}$} & \multicolumn{6}{|c|}{ Reinvestment ratio range $[0,1]$} & \multicolumn{6}{|c|}{ Reinvestment ratio range $[-1,1]$} \\
\hline & \multicolumn{3}{|c|}{ Payment day } & \multicolumn{3}{|c|}{ Payment day +10 days } & \multicolumn{3}{|c|}{ Payment day } & \multicolumn{3}{|c|}{ Payment day +10 days } \\
\hline & Div & Tender & $\mathrm{N}$ & Div & Tender & $\mathrm{N}$ & Div & Tender & $\mathrm{N}$ & Div & Tender & $\mathrm{N}$ \\
\hline \multicolumn{13}{|c|}{ Panel A: All dividends and tender offers } \\
\hline Nonfinancial corporation & 0.015 & 0.037 & 1,288 & 0.070 & 0.163 & 1,285 & 0.055 & 0.013 & 1,288 & -0.033 & 0.079 & 1,285 \\
\hline Financial corporation & 0.048 & 0.114 & 131 & 0.123 & 0.217 & 131 & -0.005 & 0.009 & 131 & -0.036 & -0.078 & 131 \\
\hline Mutual fund & 0.084 & 0.152 & 26 & 0.375 & 0.349 & 26 & -0.059 & 0.012 & 26 & 0.133 & 0.112 & 26 \\
\hline Nonprofit organization & 0.011 & 0.044 & 566 & 0.040 & 0.122 & 566 & -0.001 & 0.007 & 566 & -0.040 & 0.013 & 566 \\
\hline Household & 0.007 & 0.020 & 20,201 & 0.044 & 0.129 & 20,174 & -0.001 & 0.011 & 20,201 & -0.020 & 0.083 & 20,174 \\
\hline Foreigner & 0.008 & 0.014 & 150 & 0.043 & 0.138 & 149 & 0.016 & -0.006 & 150 & -0.030 & 0.079 & 149 \\
\hline \multicolumn{13}{|c|}{ Panel B: Dividends and tender offers greater than MDIV } \\
\hline Nonfinancial corporation & 0.035 & 0.032 & 738 & 0.118 & 0.156 & 837 & -0.001 & 0.012 & 738 & -0.023 & 0.053 & 837 \\
\hline Financial corporation & 0.077 & 0.098 & 103 & 0.144 & 0.255 & 102 & -0.004 & 0.021 & 103 & -0.042 & -0.023 & 102 \\
\hline Mutual fund & 0.187 & 0.152 & 26 & 0.388 & 0.349 & 26 & 0.035 & 0.012 & 26 & 0.157 & 0.112 & 26 \\
\hline Nonprofit organization & 0.022 & 0.030 & 485 & 0.066 & 0.131 & 494 & 0.003 & 0.009 & 485 & -0.020 & 0.025 & 494 \\
\hline Household & 0.017 & 0.014 & 7,309 & 0.081 & 0.132 & 9,010 & 0.003 & 0.009 & 7,309 & 0.005 & 0.091 & 9,010 \\
\hline Foreigner & 0.012 & 0.008 & 82 & 0.059 & 0.143 & 89 & -0.003 & -0.009 & 82 & -0.037 & 0.082 & 89 \\
\hline
\end{tabular}


The reported reinvestment ratio for mutual funds contains another useful piece of information. Because mutual funds invest on behalf of other investors, they should not accumulate excess cash reserves in the long term but rather reinvest all dividends they receive. Consider a mutual fund which reinvests $100 \%$ in the long term, and assume that the reinvestment ratio, with a range of $[-1,1]$, is an unbiased estimate for the propensity to reinvest within two weeks $(13.3 \%)$. These calculations would imply that the long-term reinvestment ratio for mutual funds is 7.5 times higher than the reported 10-day reinvestment ratio. Although this estimate may be used as a rough multiplier for interpolating long-term reinvestment ratios for other investor categories, this exercise yields estimates with very little precision.

Overall, the univariate results in Panel A of Table 3 give preliminary support to the hypothesis that the propensity to reinvest is greater for tender offer proceeds than for cash dividends. This finding is especially pronounced for households and nonprofit organizations. However, it is important not to push this argument too far as the reinvestment ratio is unconditional and for example does not account for the fact that most dividends are too small to be reinvested. Next, I investigate how much the small size of most dividends contributes to the reinvestment ratios.

Minimum lot size requirements and transaction costs make it difficult for investors to reinvest very small dividends in the stock market. In the full sample, $88 \%$ of the dividends paid to domestic households were smaller than EUR 1,000. To investigate whether the reinvestment ratios differ for payments that are sufficiently large to be reinvested as such, I remove from the full sample of dividends and tender offers all (clustered) payments that are smaller than the MDIV (see definition in Section 4.1.).

Panel $\mathrm{B}$ in Table 3 reports results for cash disbursements greater than the MDIV. Reinvestment ratios are still low, but generally higher than the full sample averages. With a 10day reinvestment window and a reinvestment ratio of $[-1,1]$, the reinvestment ratio is negative for households in the full sample and only $0.5 \%$ for dividends exceeding the MDIV. Even if I calculate the imputed long-term investment ratio based on the earlier discussion on reinvestment by mutual funds, the propensity to reinvest dividends is less than $4 \%$. This observation corroborates my earlier argument that households have a very low propensity to reinvest dividends in general, while the propensity is somewhat higher for larger dividends. For 
institutions, symmetric reinvestment ratios are close to zero or negative. Except for mutual funds, institutions are more likely to sell than buy shares after receiving a dividend. ${ }^{3}$

\subsection{A matched sample test for the degree of reinvestment}

On average, the propensity to reinvest is smaller for dividends than for tender offer proceeds, but the propensity must be conditioned before drawing final conclusions. There are two plausible factors-unrelated to any behavioral theories-which could explain why the unconditional reinvestment ratio is higher for tender offer proceeds than for dividends. First, tender offer proceed payments are much larger and often constitute a significant fraction of an investor's portfolio. Indeed, the median dividend received by a household investor is EUR 76.2, while the median tender offer proceeds are EUR 4,721.3. Second, rational investors could have chosen their portfolio composition to guarantee a certain annual dividend flow to finance consumption. If they are forced to liquidate some of their holdings in a tender offer, they can simply reinvest the proceeds to rebalance their portfolios, while an expected dividend payment of the same size does not cause a similar need for rebalancing.

I perform two experiments to investigate whether either of these claims has any merit. First, I test whether an ordinary dividend and a tender offer proceeds payment of the same size have equal reinvestment ratios. This test answers the question whether the difference in reinvestment ratios between the two cash flows is simply a size issue. Second, I perform the same test for special dividends. Corporations sometimes pay special dividends on top of the regular annual dividend, usually in the second half of the year while regular dividends are paid in the first half of the year. Special dividends are rather rare: in my sample of 916 dividend events, there are only 11 special dividends. However, these dividends are fairly large (median EUR 281 in the household sample) because they are driven by an accumulation of surplus cash reserves resulting from events such as a demerger or the sale of excess marketable securities. From an investor's perspective, special dividends are thus very similar to tender offer proceeds: they are rare, unexpected, and result in a large cash flow. By comparing tender offer proceeds and special dividends, it is possible to investigate the validity of the claim that tender offer proceeds are more

\footnotetext{
${ }^{3}$ Given the low propensity to reinvest dividends in the stock market in general, it is hardly surprising to find that the propensity to reinvest in the stock which paid the dividend is extremely low. Using a reinvestment ratio with range [$1,1]$, I find that, on average, mutual funds reinvest less than $1 \%$ of the dividend in the same stock on the payment day. For all other investor categories, the average reinvestment ratios are negative. The results are similar in the 10day window. In the light of these results, it is not surprising that there is no evidence on cumulative abnormal returns around the dividend payment day (event-day coefficient $t$-value equals -0.71 ), contrary to the findings of Ogden (1994) and Blouin and Cloyd (2005).
} 
likely to be reinvested because they are more unexpected and unwanted portfolio liquidations than ordinary dividends.

To test as cleanly as possible whether there is a difference between reinvestment of dividends and tender offer proceeds, I compare cash flows of the same size paid to the same investor. For this purpose, I first construct a value-matched sample of dividends and tender offer proceeds and then use Wilcoxon's signed rank test to compare reinvestment ratios in these two groups.

For each payment of tender offer proceeds, I pick a dividend paid to the same investor with the closest value. However, tender offer proceeds are generally larger than dividends, causing the median value of dividends to be considerably smaller. Hence, I discard every observation in which the matched dividend is less than $50 \%$ the size of the corresponding tender offer proceeds. I also experiment by changing the threshold value of $50 \%$; the results, however, are qualitatively insensitive to any reasonable changes.

I compare the reinvestment ratios of the remaining observations using Wilcoxon's signed rank test to account for the non-normal distribution of reinvestment ratios. Furthermore, I pool all investors, except for domestic households, to a single group labeled institutions and perform the signed rank test separately for ordinary and special dividends. Finally, I report the results for the symmetric measure $[-1,1]$ with 1-day and 10-day periods.

The results of the Wilcoxon's signed rank test are presented in Table 4. The table shows that households' propensity to reinvest tender offer proceeds within 10 days is greater than that of institutions, even when accounting for the size of the cash flow (results for ordinary dividends in Panel C) and when simultaneously controlling for the size and nature of the cash flow (results for special dividends in Panel D).

There is also evidence that the propensity to reinvest tender offer proceeds within 10 trading days is higher for institutions. However, at this stage, speculating with this finding would not be justified as the subsample of institutions is relatively small and consists of various investor types. In summary, the results for 10 trading days indicate that tender offer proceeds are more likely to be reinvested than dividends, a finding which is consistent with the results for unconditional reinvestment ratios reported in Table 3.

With the 1-day specification, the results are somewhat weaker. There is a statistically significant difference between tender offer proceeds and ordinary dividends for institutions, but not for households. The reverse is true for special dividends. The lack of a consistent difference 
in the 1-day window is most likely due to a lack of statistical power because of the smaller sample size.

Table 4

Test for the equality of unconditional reinvestment ratios between tender offer proceeds and dividends

This table reports Wilcoxon's signed rank test Z-values for the difference in reinvestment ratios of tender offer proceed payments and (special) dividends. The null hypothesis for the test is that median of reinvestment ratio tender $_{-}$ reinvestment ratio $_{\text {dividend }}$ in the matched sample equals zero. Reinvestment ratio definitions are as in Table 3. All tender offer proceeds must be greater than the MDIV (see Section 4.1.) and they are value-matched with the (extra) dividend paid to the same investor. The value of the matched dividend must also be at least $50 \%$ the value of the corresponding tender offer proceeds. All investors, other than domestic households, are aggregated to a single group labeled institutions. The three rightmost columns report statistics for the size of the cash flow. Z-value is the Wilcoxon's test statistic, tender offer $>$ dividend (dividend $>$ tender offer) number of cases when the reinvestment ratio is greater for tender offer (dividend), and $\mathrm{N}$ is the total number of observations in the sample. Median dividend and median tender offer proceeds are matched sample median cash flow values. Dividend $>$ tender, \% of cases corresponds to the percentage of cases where the matched-pair dividend is greater than the tender offer proceeds. Asterisks mark statistical significance at conventional levels (** for $5 \%$ and $* * *$ for $1 \%$, respectively).

Period Wilcoxon's paired sample test statistics

Z-value

$\begin{array}{cc}\text { Tender } & \text { Dividend } \\ \text { offer }> & >\text { tender } \\ \text { dividend } & \text { offer }\end{array}$

Sample median values, EUR

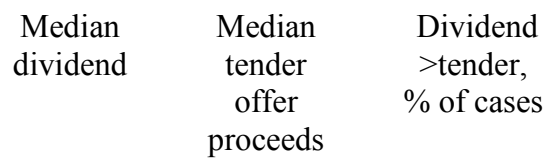

Payment day

Panel A: Reinvestment ratios with range $[-1,1]$, tender offer versus matched dividend

\begin{tabular}{lccccccc}
\hline Households & 0.22 & 65 & 60 & 1,679 & 2,442 & 3,007 & $42.2 \%$ \\
Institutions & $2.82 * * *$ & 58 & 31 & 323 & 5,512 & 6,400 & $46.4 \%$ \\
\hline \multicolumn{7}{l}{ Panel B: Reinvestment ratios with range [-1, 1], tender offer } & versus matched special dividend \\
\hline Households & $3.38^{* * *}$ & 60 & 27 & 915 & 5,000 & 3,200 & $52.0 \%$ \\
Institutions & -0.60 & 49 & 38 & 268 & 14,853 & 6,609 & $66.4 \%$
\end{tabular}

Payment day +10 days

\begin{tabular}{lccccccc}
\hline Panel C: Reinvestment ratios with range [-1, 1], tender offer versus matched dividend \\
\hline Households & $10.11^{* * *}$ & 1,393 & 950 & 6,443 & 3,619 & 9,660 & $35.8 \%$ \\
Institutions & $3.47^{* * *}$ & 358 & 270 & 1,287 & 16,805 & 16,200 & $54.7 \%$ \\
\hline \multicolumn{7}{l}{ Panel D: Reinvestment ratios with range [-1, 1], tender offer versus matched special dividend } \\
\hline Households & $2.30^{* *}$ & 219 & 179 & 914 & 5,000 & 3,200 & $52.0 \%$ \\
Institutions & $3.11^{* * *}$ & 89 & 52 & 268 & 14,853 & 6,609 & $66.4 \%$ \\
\hline
\end{tabular}

I also check that these results are not driven by time variation in the number of tender offers and dividend payments. In fact, there were 13 tender offers in 2001 whereas in 1995 there was only one tender offer. Although they increase over the sample period, the annual number and gross value of dividend payments are more stable. If the propensity to reinvest is very high when the takeover market is active, the propensity to reinvest tender offer proceeds will be higher in the pooled data. To see whether time variation in reinvestment ratios is an issue, I re-estimate the results for Panel $\mathrm{C}$ (the only case where there are enough remaining observations for a statistical 
test with a reasonable sample size) reported in Table 4 by setting an additional requirement that the matched dividend was paid in the year of the tender offer. The results (unreported) are qualitatively similar for both windows: households and institutions still have a higher propensity to reinvest tender offer proceeds in the 10-day window.

\subsection{A dynamic approach}

This subsection introduces a dynamic approach to study how payments of dividends and tender offer proceeds drive stock market investments. By investigating reinvestment activity with a lagged variable regression specification, it is possible to confirm earlier results and to verify whether the selected lag of ten days is a sufficiently long period to capture the impact of corporate cash disbursements on investor trading. I model the trades of an investor around the dividend and tender offer proceeds payments as a simple dynamic system with the following autoregressive distributed lags (ARDL) specification:

$$
x_{t}=\alpha+\theta_{t-n} \sum_{n=1}^{20} x_{t-n}+\Delta_{t-n} \sum_{n=0}^{20} d_{t-n}+\varepsilon_{t} .
$$

In the equation above, $x_{t}$ refers to net investment in the stock market by the investor on day $t$ and $d_{t}$ indicates a payment of dividends or tender offer proceeds on the same day. Hence, the specification can be understood as a system of current investment responding to impulses of past investments and cash flows.

Considerable variation and extreme values cause problems in estimating Equation 1 without variable transformations. I make the model behave better by using a simplification similar to Hasbrouck (1991) and replace the net value of investment on day $t$ and the corresponding lagged values with an indicator function taking values $-1,0$, and 1 . In other words, I only consider the sign of net investment. For dividends, I use log-transformed values.

Table 5 reports results for the ARDL specification. On the left-hand side of the table, I report results for dividends, and correspondingly, for tender offers on the right-hand side. In both samples, I use a 20-day lag and require the cumulative value of corporate cash disbursement within the lag period to be greater than MDIV (see definition in Section 4.1.) for the observation to enter the sample. The latter restriction is imposed for the sake of computational feasibility: even with this size restriction, I have almost 4.4 million observations to deal with. In summary, there is one observation for every trading day in which an investor has received cash disbursement(s) at least worth the MDIV during the preceding 20 trading days. 
Table 5

The effect of corporate cash disbursement on net flow to the stock market

This table reports results from regressing investor trading activity on past trades and payments of dividends and tender offer proceeds. The dependent variable is an indicator function of trade and has a value of 1 if an investor has a positive net flow to the stock market on day $0,-1$ if negative, and zero otherwise. The lagged values for net trades are defined correspondingly. Contemporary and lagged values for dividends are log-transformed values. The observations include all trading days when an investor received corporate cash disbursements exceeding the MDIV (see Section 4.1) over a period of past 20 days. Coefficients are estimated by ordinary least squares. All reported unstandardized coefficient values correspond to original values multiplied by 1,000 . Asterisks mark statistical significance at conventional levels (* for $10 \%, * *$ for $5 \%$, and $* * *$ for $1 \%$, respectively).

\begin{tabular}{|c|c|c|c|c|c|c|c|c|c|c|c|c|}
\hline & \multicolumn{6}{|c|}{ Dividends } & \multicolumn{6}{|c|}{ Tender offers } \\
\hline & \multicolumn{3}{|c|}{ Households } & \multicolumn{3}{|c|}{ Institutions } & \multicolumn{3}{|c|}{ Households } & \multicolumn{3}{|c|}{ Institutions } \\
\hline & Coeff. & $t$-value & & Coeff. & $t$-value & & Coeff. & $t$-value & & Coeff. & $t$-value & \\
\hline Intercept & 0.52 & 2.55 & & -1.32 & -2.11 & $* *$ & 2.91 & 1.68 & & -1.68 & -0.61 & \\
\hline Cash disbursement at $t$ & 0.39 & 8.35 & $* * *$ & -0.42 & -2.84 & $* * *$ & 2.24 & 8.64 & $* * *$ & 2.67 & 3.18 & $* * *$ \\
\hline$t-1$ & 0.49 & 10.58 & $* * *$ & 0.31 & 2.12 & $* *$ & 3.53 & 13.69 & $* * *$ & 2.68 & 3.20 & $* * *$ \\
\hline$t-2$ & 0.20 & 4.46 & $* * *$ & 0.35 & 2.33 & $* *$ & 1.67 & 6.49 & $* * *$ & 0.83 & 0.99 & \\
\hline$t-3$ & 0.07 & 1.53 & & 0.08 & 0.57 & & 1.22 & 4.75 & $* * *$ & 1.63 & 1.94 & $*$ \\
\hline$t-4$ & -0.09 & -1.95 & $*$ & -0.17 & -1.14 & & 1.36 & 5.30 & $* * *$ & -1.49 & -1.77 & $*$ \\
\hline$t-5$ & -0.02 & -0.43 & & 0.45 & 3.00 & $* * *$ & 1.04 & 4.07 & $* * *$ & 0.57 & 0.68 & \\
\hline$t-6$ & 0.11 & 2.56 & $* *$ & -0.34 & -2.28 & $* *$ & 1.04 & 4.03 & $* * *$ & 0.20 & 0.24 & \\
\hline$t-7$ & -0.05 & -1.09 & & -0.08 & -0.53 & & 0.65 & 2.52 & $* *$ & -0.32 & -0.38 & \\
\hline$t-8$ & 0.15 & 3.40 & $* * *$ & 0.06 & 0.39 & & 0.26 & 1.01 & & -1.57 & -1.87 & $*$ \\
\hline$t-9$ & 0.22 & 4.89 & $* * *$ & 0.39 & 2.63 & $* * *$ & 0.58 & 2.26 & $* *$ & 0.15 & 0.18 & \\
\hline$t-10$ & -0.02 & -0.36 & & 0.59 & 4.00 & $* * *$ & 0.57 & 2.23 & $* *$ & -1.53 & -1.82 & $*$ \\
\hline$t-11$ & -0.14 & -3.17 & $* * *$ & -0.24 & -1.58 & & 0.73 & 2.84 & $* * *$ & 0.58 & 0.69 & \\
\hline$t-12$ & -0.02 & -0.36 & & -0.14 & -0.92 & & 0.38 & 1.49 & & 0.16 & 0.19 & \\
\hline$t-13$ & 0.11 & 2.39 & $* *$ & -0.20 & -1.33 & & 0.33 & 1.27 & & -1.89 & -2.25 & ** \\
\hline$t-14$ & -0.06 & -1.24 & & -0.96 & -6.47 & $* * *$ & 0.34 & 1.31 & & -1.30 & -1.55 & \\
\hline$t-15$ & -0.27 & -5.97 & $* * *$ & -0.78 & -5.23 & $* * *$ & 0.60 & 2.33 & $* *$ & 1.27 & 1.51 & \\
\hline$t-16$ & -0.13 & -2.81 & $* * *$ & -0.76 & -5.14 & $* * *$ & 0.24 & 0.95 & & -1.70 & -2.02 & $* *$ \\
\hline$t-17$ & 0.03 & 0.74 & & 0.34 & 2.27 & $* *$ & 0.49 & 1.92 & $*$ & 0.39 & 0.47 & \\
\hline$t-18$ & 0.29 & 6.24 & $* * *$ & 0.86 & 5.82 & $* * *$ & 0.47 & 1.84 & $*$ & 1.25 & 1.48 & \\
\hline$t-19$ & 0.34 & 7.40 & $* * *$ & 0.50 & 3.36 & $* * *$ & 0.14 & 0.55 & & -0.92 & -1.09 & \\
\hline$t-20$ & 0.37 & 7.93 & $* * *$ & 0.57 & 3.81 & $* * *$ & 0.66 & 2.55 & $* *$ & 1.55 & 1.85 & $*$ \\
\hline Trade at $\mathrm{t}-1$ & 44.01 & 82.47 & $* * *$ & 74.53 & 69.14 & $* * *$ & 56.13 & 32.56 & $* * *$ & 8.66 & 2.09 & $* *$ \\
\hline$t-2$ & 20.28 & 37.99 & $* * *$ & 46.71 & 43.23 & $* * *$ & 34.76 & 20.22 & $* * *$ & 29.44 & 7.10 & $* * *$ \\
\hline$t-3$ & 11.99 & 22.46 & $* * *$ & 33.90 & 31.36 & $* * *$ & 13.43 & 7.95 & $* * *$ & 25.82 & 6.26 & $* * *$ \\
\hline$t-4$ & 12.10 & 22.65 & $* * *$ & 34.29 & 31.71 & $* * *$ & 12.20 & 7.24 & $* * *$ & 27.56 & 6.67 & $* * *$ \\
\hline$t-5$ & 9.98 & 18.68 & $* * *$ & 32.58 & 30.12 & $* * *$ & 10.64 & 6.31 & $* * *$ & 19.55 & 4.73 & $* * *$ \\
\hline$t-6$ & 10.33 & 19.35 & $* * *$ & 19.89 & 18.39 & $* * *$ & 16.23 & 9.63 & $* * *$ & 25.76 & 6.24 & $* * *$ \\
\hline$t-7$ & 11.83 & 22.20 & $* * *$ & 24.14 & 22.34 & $* * *$ & 11.19 & 6.63 & $* * *$ & 39.11 & 9.49 & $* * *$ \\
\hline$t-8$ & 10.91 & 20.55 & $* * *$ & 21.45 & 19.85 & $* * *$ & 6.34 & 3.75 & $* * *$ & 32.84 & 7.96 & $* * *$ \\
\hline$t-9$ & 7.18 & 13.55 & $* * *$ & 13.02 & 12.06 & $* * *$ & 11.82 & 6.97 & $* * *$ & 24.49 & 5.94 & $* * *$ \\
\hline$t-10$ & 8.45 & 15.99 & $* * *$ & 19.07 & 17.67 & $* * *$ & 8.46 & 4.97 & $* * *$ & 49.77 & 12.07 & $* * *$ \\
\hline$t-11$ & 7.07 & 13.41 & $* * *$ & 23.65 & 21.92 & $* * *$ & 5.53 & 3.24 & $* * *$ & 18.52 & 4.50 & $* * *$ \\
\hline$t-12$ & 6.71 & 12.76 & $* * *$ & 15.63 & 14.49 & $* * *$ & 11.46 & 6.70 & $* * *$ & 19.70 & 4.79 & $* * *$ \\
\hline$t-13$ & 7.08 & 13.46 & $* * *$ & 19.88 & 18.43 & $* * *$ & 9.54 & 5.58 & $* * *$ & 24.59 & 5.97 & $* * *$ \\
\hline$t-14$ & 9.37 & 17.85 & $* * *$ & 12.74 & 11.81 & $* * *$ & 15.08 & 8.82 & $* * *$ & -4.13 & -1.00 & \\
\hline$t-15$ & 7.04 & 13.43 & $* * *$ & 18.48 & 17.15 & $* * *$ & 5.01 & 2.92 & $* * *$ & 18.98 & 4.61 & $* * *$ \\
\hline$t-16$ & 4.78 & 9.11 & $* * *$ & 14.03 & 13.02 & $* * *$ & 4.27 & 2.47 & $* *$ & 31.18 & 7.58 & $* * *$ \\
\hline$t-17$ & 4.62 & 8.81 & $* * *$ & 10.99 & 10.21 & $* * *$ & 4.01 & 2.31 & $* *$ & 12.11 & 2.95 & $* * *$ \\
\hline$t-18$ & 4.98 & 9.50 & $* * *$ & 10.24 & 9.51 & $* * *$ & 11.14 & 6.41 & $* * *$ & 17.93 & 4.37 & $* * *$ \\
\hline$t-19$ & 4.73 & 9.01 & $* * *$ & 11.19 & 10.41 & $* * *$ & 6.48 & 3.71 & $* * *$ & 12.64 & 3.08 & $* * *$ \\
\hline$t-20$ & 5.28 & 10.07 & $* * *$ & 7.00 & 6.53 & $* * *$ & 10.20 & 5.77 & $* * *$ & 28.92 & 7.05 & $* * *$ \\
\hline F-test statistic & & & 89.64 & & & 577.31 & & & 75.87 & & & 33.13 \\
\hline$R^{2}$ & & & 0.005 & & & 0.027 & & & 0.009 & & & 0.023 \\
\hline Number of observations & & & 2,058 & & & 59,207 & & & 34,793 & & & 58,134 \\
\hline
\end{tabular}


Panel A: Households
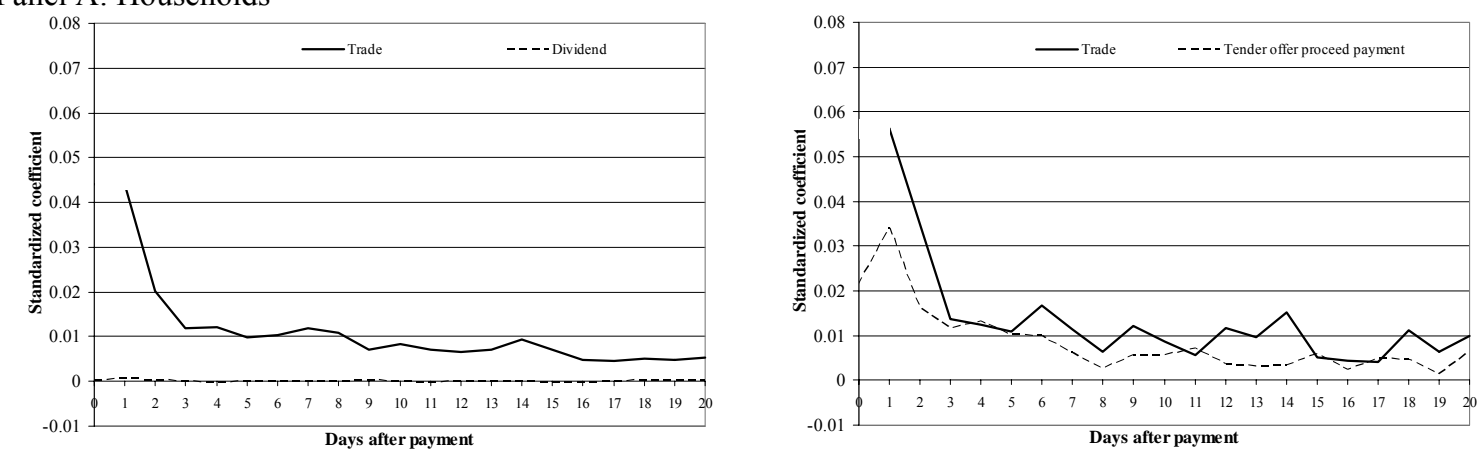

Panel B: Institutions
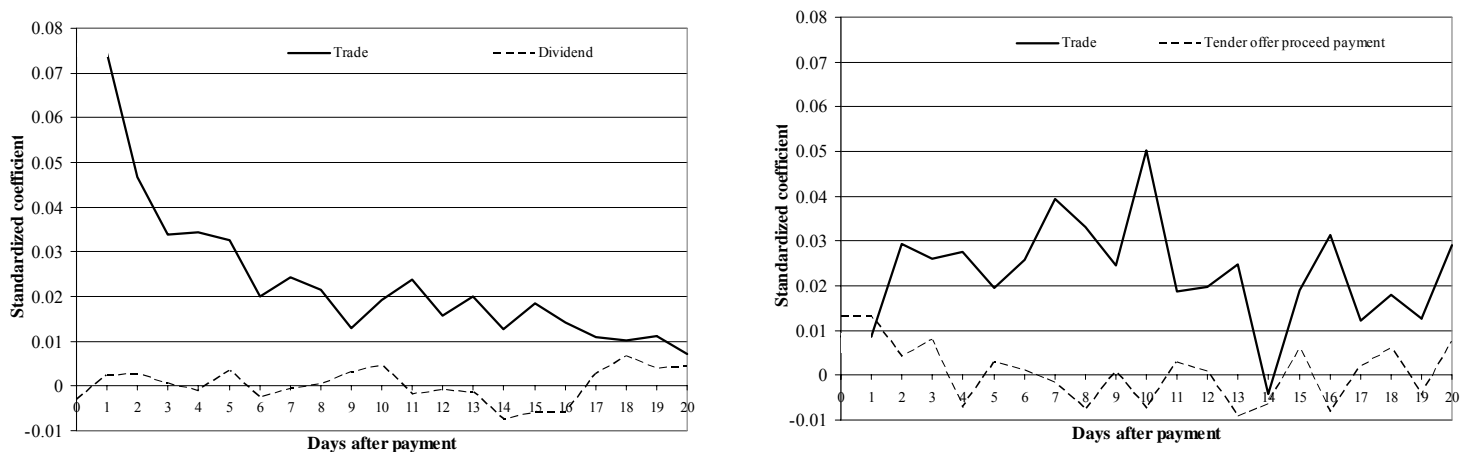

Fig. 3. Visual representation of standardized coefficients from Table 5

Panel A: Households
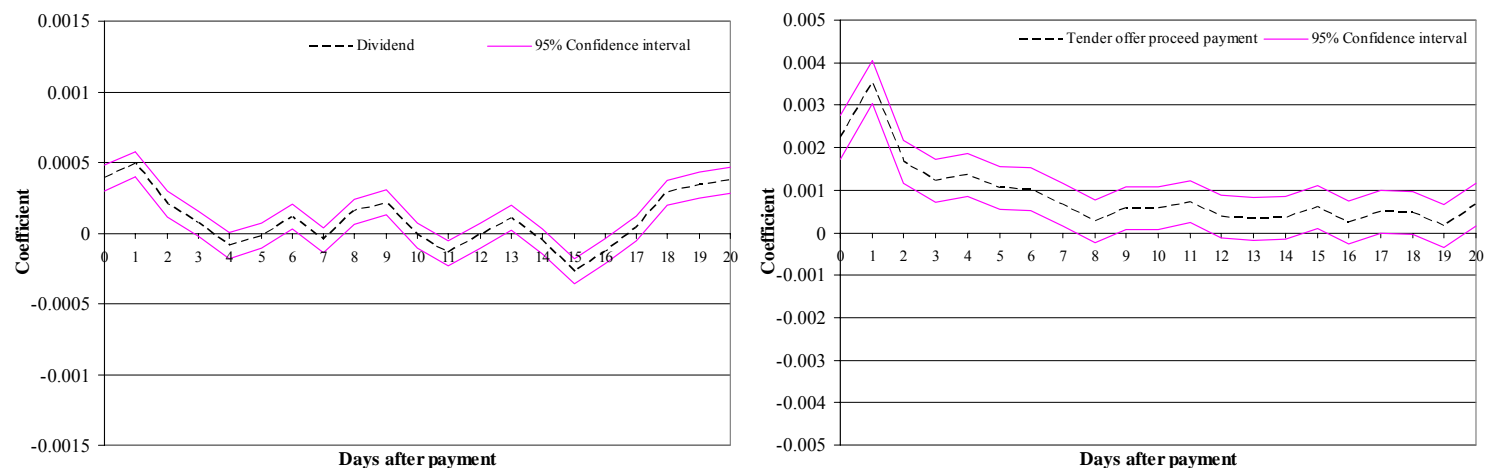

Panel B: Institutions
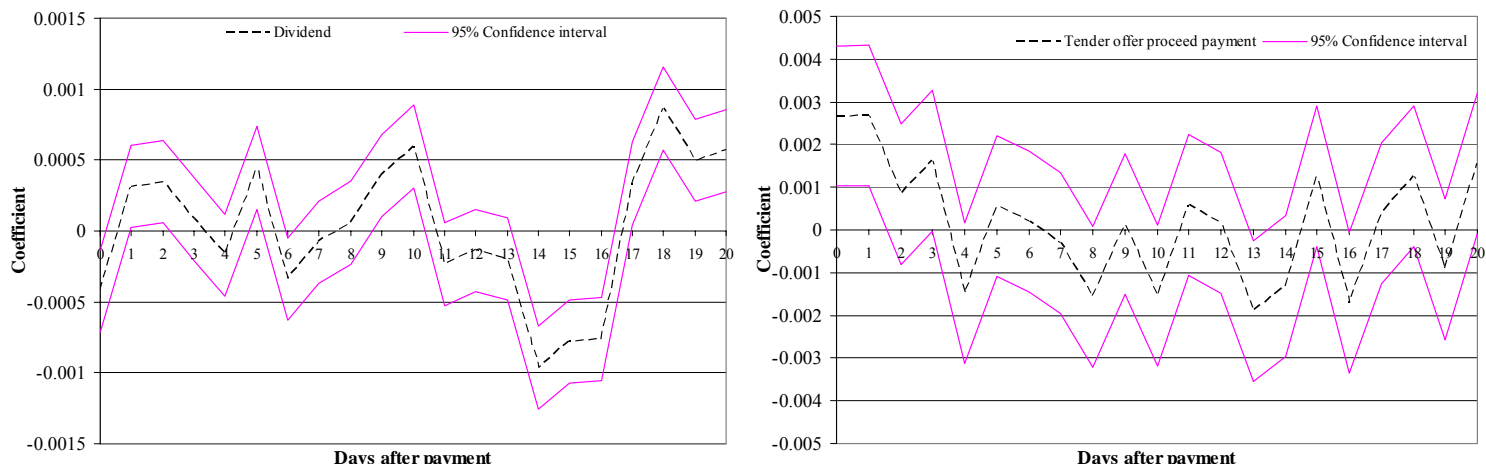

Fig. 4. Cash flow coefficients from Table 5. 
The results in Table 5 clearly indicate that the impact of receiving a tender offer proceeds payment is larger than the impact of receiving a dividend. This finding is visually demonstrated in Figure 3 for standardized coefficients. Clearly, there is a difference between dividends and tender offer proceeds for households, while the cash flow coefficients behave erratically around zero in the sample of institutions. The decay of coefficients in Figure 4 suggests that the initially selected 10-day period is enough to capture the impact of a corporate cash disbursement on investor trading. Household investors who reinvest corporate cash disbursements do so relatively quickly, although not immediately: both dividend and tender offer proceeds coefficients peak at $t$ -1 . The cash disbursement coefficient is no longer significant at $t-3$ for dividends and at $t-8$ for tender offer proceeds.

The validity of ordinary least squares as an estimation method might be challenged because the dependent variable is limited to only three discrete values. Although I also re-estimate the results of Table 5 by fitting an ordered logit model with maximum likelihood estimation, quantitative change in the results (unreported) is very small. For example, in the sample of households, the cash flow coefficient is no longer significant at $t-3$ for dividends and at $t-8$ for tender offer proceeds.

\subsection{What drives the decision to reinvest?}

Up to this point, this study has documented results for unconditional reinvestment ratios and parsimonious empirical tests. The evidence so far points toward the conclusion that the propensity to reinvest is greater for tender offer proceeds than for dividends. Although keeping the most important factors constant, these analyses have not yet simultaneously controlled for all possible determinants of the propensity to reinvest. The purpose of the analysis in this subsection is to test whether the propensity to reinvest is greater for tender offer proceeds than for dividends, while simultaneously controlling for factors such as size of the cash payment, past return of the market index, size of the investor's portfolio, and investor age.

Slightly altering the methodology used in Grinblatt and Keloharju (2001), I run a pooled buy/sell logit regression by coding strictly positive investments in the stock market as ones and strictly negative investments as zeros. Grinblatt and Keloharju (2001) use individual transactions as the dependent variable, while I use net daily flows to capture the direction of total reinvestment activity rather than individual trades. As in the previous analyses, I report results for two different lags, and further break the sample down to institutions and households. In addition, 
to not let the very small dividends to influence the results, I discard cash disbursements smaller than the MDIV (see Section 4.1).

The explanatory variables in the buy/sell regression can be divided to cash disbursement and control variables. Cash disbursement variables include a dummy for special dividends, a dummy for tender offers, and three dummies for the stage of tender offer as described in Section 3.5. If an investor receives several dividends or tender offer proceeds on the same trading day, I aggregate these cash flows to a single observation. Correspondingly, in the 10-day specification, all dividend payments or tender offer proceeds clustered within 10 days are aggregated, as described in Section 4.2. Control variables include dummies for each investor category (nonfinancial firm dummy omitted in the sample of institutions), the natural logarithm of portfolio value, the log value of cash disbursement, and the investor's cumulative gross portfolio return for the previous 12 months. I define the portfolio variable return consistent with Barber and Odean (2001) and calculate it at the beginning of each month. I also control for past market returns with 11 variables consistent with Grinblatt and Keloharju (2001), and include a full set of year dummies. In addition, there are seven dummies for age and one for sex in the sample of households.

Both 1-day and 10-day specifications have their own strengths and limitations. The strength of the 1-day specification is that the cash disbursement occurs on the same trading day as the measured net investment. In contrast, in the 10-day specification, cash flows and trades are aggregated over a 10-day period, which may cause some loss of precision: this is because the longer the reinvestment period, the less traceable is the link between cash flow and investment. On the other hand, 10-day samples are larger and do not rely on the rather stringent assumption that investors react immediately and trade on the day of the cash disbursement. I therefore report results for both lags.

The results reported in Table 6 corroborate the argument that households are more likely to reinvest tender offer proceeds than dividends, all other things being equal. The size of cash flow has a positive and significant coefficient in the 10-day specification as expected, but the tender offer dummy is highly significant, even though cash flow size is controlled for. In both specifications for households, the coefficient for the tender offer dummy is positive and significant, with $t$-values 4.70 and 12.90 . For institutions, the coefficient for tender offer is only marginally significant in the 1-day specification. This is not surprising, given the rather erratic dynamic regression coefficients shown in Panel B of Figure 4. 
Table 6

Determinants of the propensity to buy versus sell after a corporate cash disbursement

This table reports the results for an investor's choice to reinvest a cash dividend or proceeds from a sale of tendered stock. The dependent variable takes the value of 1 if an investor has positive net investment in the stock market after a dividend or tender offer proceeds payment, and 0 if the net investment is negative. The two leftmost specifications report results for the day of cash disbursement, the two rightmost for the day and subsequent 10 days. The sample includes all investors who traded after a cash disbursement, and the value of cash disbursement is required to be greater than the MDIV, as described in section 4.1. Dividends or tender offer proceeds payments clustered within 10 days are aggregated as described in Section 4.2. 12 month portfolio return is calculated with monthly data and measured at the beginning of the month. The tender offer dummy has a value of 1 if the cash disbursement is tender offer proceeds, 0 if a dividend. The other three dummies are for three stages of tender offers as described in Section 3.5. A tender offer with a bidder owning less than $2 / 3$ is the reference level, and has no dummy variable. Special dividend is a dummy for an additional dividend paid by the company on top of the regular annual dividend. Financial corporation, mutual fund, nonprofit organization, and foreigner are dummies for the representative investor categories, the dummy for the category nonfinancial firm is omitted in the sample of institutions. Ln (portfolio value +1 ) is the natural logarithm of portfolio value one day prior to first cash disbursement and Ln (value of cash disbursement) the log value of cash dividend or tender offer proceeds. In the case of clustered dividends, the value of special dividend and the value of portfolio are determined by the day of the last cash disbursement. Past market index returns (not reported) are defined consistent with Grinblatt and Keloharju (2001), and correspond to arithmetic returns of the HEX Portfolio Index prior to the (last) day of the cash disbursement. Age and sex dummies (not reported) are 7 binary variables for age and one for sex. All specifications include 7 year dummies (not reported). Asterisks mark the statistical significance at conventional levels $(*$ for $10 \%, * *$ for $5 \%$, and $* * *$ for $1 \%$, respectively).

Dependent variable $\quad$ Binary: 1 if the investor has a positive cumulative net investment in the stock market after a cash disbursement, 0 if negative

Specification

Reinvestment lag

Sample

\begin{tabular}{ccccc}
\multicolumn{4}{c}{ market after a cash disbursement, 0 if negative } \\
\hline \multicolumn{3}{c}{ Logit } \\
\cline { 1 - 3 } \cline { 4 - 5 } Day of payment & & Day of payment +10 days \\
\hline Households & Institutions & & Households & Institutions \\
\hline 0.46 & $0.95^{* * *}$ & & $0.35^{* *}$ & -0.05 \\
1.01 & 3.08 & 2.01 & -0.31 \\
-0.07 & -0.07 & 0.001 & 0.004 \\
-1.61 & -1.61 & 0.21 & 0.41
\end{tabular}

Constant

12 month portfolio return

Variables for the type of cash disbursement

Tender offer

$\begin{array}{cc}0.87 * * * & 0.62 * \\ 4.70 & 1.92 \\ 0.39 & 0.99 * * \\ 1.62 & 2.05 \\ & \\ 0.12 & -1.69 * \\ 0.37 & -1.91 \\ -2.13 * * & \mathrm{a}) \\ -2.28 & \\ 0.34 & 0.01 \\ 0.63 & 0.02\end{array}$

$0.90 * * *$

0.14

Mandatory bid at 2/3 ownership

Right for compulsory acquisition at $90 \%$ ownership

Forced redemption

Special dividend

Size variables

Ln (portfolio value +1 )

$-0.01$

$-0.81$

$0.05^{*}$

Investor category dummies

Financial corporation

Mutual fund

Nonprofit organization

Foreigner

Age and sex dummies

Past market index returns

Year dummies

McFadden's pseudo $R^{2}$

Chi-square statistic

Number of observations
Included

Included

Included

0.032

342.76

8,124
1.81

$-2.51$

12.90
$0.38 * * *$

4.09

1.30

$0.36 * *$

$-0.27 * *$

$0.41 *$

$-2.05$

$-0.69 * * *$

1.67

$-2.61-0.82$

$-0.25 * * * \quad 0.03$

$\begin{array}{ll}-2.82 & 0.23\end{array}$

$\begin{array}{cc}-0.11 * * * & -0.02 * \\ -11.51 & -1.70 \\ 0.11 * * * & -0.005 \\ 8.89 & -0.38\end{array}$

a) No observations in the sample.

$\begin{array}{ccc}0.19 * & & -0.01 \\ 1.78 & & -0.14 \\ 0.20 & & 0.53 * * * \\ 1.00 & & 5.51 \\ 0.11 & & 0.02 \\ 1.49 & & 0.37 \\ -0.08 & & -0.03 \\ -0.42 & \text { Included } & -0.26 \\ & \text { Included } & \text { Included } \\ \text { Included } & \text { Included } & \text { Included } \\ \text { Included } & 0.044 & 0.020 \\ 0.027 & 2229.63 & 343.10 \\ 173.04 & 36,488 & 12,531 \\ 4,574 & & \end{array}$

$-0.05 * * *$
-3.06
$-0.06 * *$
-2.51

.70

0.38 
In a large portfolio, a cash disbursement has a smaller probability of being reinvested than in a small portfolio. There are two plausible explanations for this. First, if a EUR 1,000 dividend is paid to an investor with a EUR 1,000,000 portfolio, the dividend is probably far too small to cause much action, whereas the same dividend paid to a less affluent investor may trigger a reinvestment. Second, the number of stocks in a portfolio is correlated with portfolio value. Given the difficulty of short selling in the Finnish market, an investor with several stocks in a portfolio has several candidates for a sale, whereas an investor with no stocks in the portfolio can only buy.

In the 10-day specification for households, the special dividend dummy is negative and significant. This suggests that at least for households, special dividends are in terms of the BLC hypothesis even deeper in the current income account and less likely to be reinvested than ordinary dividends. In other words, households which receive special dividends, in addition to the regular annual dividend cash flow, consider the special dividends as extra income to be spent. This finding for special dividends is consistent with the earlier argument that the difference in reinvestment ratios for dividends and tender offer proceeds cannot be fully explained by the fact that tender offers are unexpected and constitute a larger fraction of an investor's portfolio. If this alternative argument were to gain support in the data, special dividends would have a higher probability of reinvestment because they are more unexpected and larger than ordinary dividends. This is not the case, however.

Results for the different stages of tender offers indicate that investors who tender their shares early are more likely to reinvest the proceeds than those who tender only after the bidder has acquired $90 \%$ ownership. One potential explanation is that investors couple the decisions of tendering and reinvesting. Perhaps, investors who tender in the initial stage of a takeover do so because they have also decided where to invest the proceeds. In contrast, in the later stage of a takeover, there may be several investors who have not decided what to do with the funds, but are nevertheless forced to tender.

The results for control variables can be compared with the earlier analyses in this paper as well as with the results from earlier studies. There are three findings worth pointing out here. First, in the sample of institutions, mutual funds have a higher propensity to reinvest. This is also the case for unconditional reinvestment ratios greater than the MDIV in Panel B of Table 3. Second, the unreported age dummies form a pattern similar to the results in Grinblatt and Keloharju (2001), indicating that rational life-cycle considerations also play a role in the reinvestment decision. The elderly are most likely to sell rather than buy, whereas the behavior of 
the young investors is exactly the opposite. However, it must be emphasized here that even if lifecycle considerations are relevant in the reinvestment decision, they fail to explain why there is a difference between reinvesting dividends and reinvesting tender offer proceeds. Third, unreported coefficients for past market returns are consistent with the results of Grinblatt and Keloharju (2001). In particular, households have a higher propensity to buy than to sell if the market has gone down prior to a cash disbursement.

I also perform a robustness check to control for the value of corporate cash disbursement as a fraction of portfolio value. In the baseline logit model, I include separate variables for cash flow size and portfolio value. However, including a further variable for the fraction of portfolio value would be susceptible, because this variable would, by definition, be correlated with the cash flow size and portfolio value variables. Therefore, I re-estimate the results in Table 6 by replacing portfolio value and size of the cash flow with a single variable, size of the cash flow divided by portfolio value. The results (unreported) remain qualitatively similar.

Overall, the results in this section give strong support for the argument that households label cash flows as dividends and principal, and are more likely to reinvest tender offer proceeds than dividends. In the concluding section, I discuss whether the difference in reinvestment ratios can be rationalized with an explanation other than mental accounting.

\section{Conclusions}

This study examines the extent to which investors reinvest dividends and tender offer proceeds in the stock market. Because the market must clear, and almost all investors receive dividends in the long-term, the long-term aggregate reinvestment ratio of all investors is zero. However, not every investor receives dividends on every trading day. It is therefore possible that investors with excess liquidity buy stocks in the short-term, and the aggregate reinvestment ratio is positive.

The results show that households reinvest only a very small fraction of dividends in the short-term. Institutional investors are not reinvesting either, with the exception of mutual funds. I estimate that households probably reinvest less than $1 \%$ of dividends within two weeks of the payment. Even with a very aggressive measure, households reinvest no more than $8.1 \%$ of the dividends. Yet, these figures do not include the most passive investors, which would further bring down the estimated reinvestment ratios.

The market clearing condition does not prevent individual investors from treating dividends and tender offer proceeds differently in their mental calculus. I hypothesize that households in 
particular may segregate dividends and capital assets into different mental accounts and that they would be more likely to reinvest tender offer proceeds that belong to the capital asset account. In fact, this is what I find in the data. The propensity to reinvest tender offer proceeds is higher than for dividends, and this result is robust when controlling for the size and unexpectedness of receiving tender offer proceeds. There is also similar, but weaker, evidence for institutions.

There are several potential explanations as to why the overall reinvestment activity in the short-term is so low. Finding out what really drives the low reinvestment activity is beyond the scope of this study, but some of the potential explanations are discussed below.

Status quo bias (Samuelson and Zeckhauser, 1988; Baker, Coval, and Stein, 2004) offers an interpretation of why investors only infrequently reinvest dividends and tender offer proceeds. When the bank account of an investor is credited, reinvesting the funds requires a self-initiated action. Although perhaps intuitively appealing, this interpretation does not explain why household investors are more likely to reinvest tender offer proceeds than dividends, all other things being equal. Hence, even though status quo bias may be relevant for interpreting the aggregate finding of a low propensity to reinvest dividends and tender offer proceeds in the shortterm, it does not explain a difference in the way these two income sources are treated.

One potential interpretation of the low propensity to reinvest is that household investors want cash disbursements at regular intervals to minimize transaction costs and the capital gains tax resulting from the sales of securities. ${ }^{4}$ However, this explanation is inconsistent with the finding that tender offers and special dividends of the same size-both unexpected and large cash flows-are treated differently. This indicates that the small absolute degree of dividend reinvestment and the difference in reinvestment of tender offer proceeds and dividends cannot be fully explained by the existence of rational dividend clienteles.

Another possible explanation for the low reinvestment ratios is that Finnish households invested dividends and tender offer proceeds to mutual funds, rather than to stocks, during the sample period. Two factors seriously undermine the validity of this explanation. First, the correlation between the monthly value of dividends paid to domestic shareholders and their net flow to mutual funds is indistinguishable from zero. ${ }^{5}$ Second, unreported year dummies in regressions of Table 6 indicate that there was an upward trend in the propensity to reinvest,

\footnotetext{
${ }^{4}$ In Finland, capital gains were taxed at $25-29 \%$ during the sample period. In contrast, the imputation system guaranteed an effective tax rate of $4 \%$ for dividends in fiscal year 1996, 1.4\% in fiscal year 2000, and zero in fiscal years 1995, 1997-1999, and 2001-2002.

${ }^{5}$ I perform this test by using monthly data on aggregate mutual fund flows from 1997-2002 (data are unavailable for 1995-1996). The correlation coefficient is 0.12 , yielding a $t$-value of 0.98 , with 71 observations. The data are from Rahastoraportti), a monthly publication on mutual funds registered in Finland.
} 
although household investments in mutual funds rose steadily over the sample period. ${ }^{6}$ These two facts suggest that a systematic redirection of corporate cash disbursements from direct stock investments to mutual funds is unlikely to explain the low reinvestment ratios. In addition, even a migration from stocks to mutual funds would fail to explain the wedge between the propensity to reinvest dividends and tender offer proceeds.

Taxes might also influence the reinvestment decision. In Finland, the effective tax rate for dividends is zero for domestic taxable investors, but capital gains on tendered shares are taxed. However, taxes work against the alternative hypothesis. If investors consider taxes when they make the decision to reinvest, they should leave some of the tender offer proceeds uninvested to pay taxes later. In contrast, dividends can be fully reinvested because they are effectively not taxed.

Overall, my results are consistent with the argument that the labeling of cash flows can influence investor behavior (e.g., Thaler, 1999). My findings have at least two practical implications. First, a dividend paid to the investor's account is unlikely to be returned to the stock market. Individuals for whom transaction costs are not an issue and who are willing to increase saving, could consider an agreement with their stockbroker to reinvest dividends promptly. This proposed course of action is consistent with Benartzi and Thaler (2004), who argue that due to self-control problems, it is often optimal for an individual's long-term welfare to make precommitments for saving. Second, when financial instruments are marketed to retail investors, it may make a difference whether a certain cash flow is labeled as a return of principal, rather than interest or dividend.

Although household investors tend to reinvest tender offer proceeds than dividends, the fraction of reinvested tender offer proceeds is surprisingly small. While it seems that households do consider the source of income when deciding whether to reinvest or not, they do not always follow the rule of thumb "never touch the principal." The relatively small propensity to reinvest tender offer proceeds suggests that touching the principal is allowed at least when it has already been forcefully touched by the bidder.

\footnotetext{
${ }^{6}$ According to the Finnish Bankers' Association, households had less than $1 \%$ of their financial assets in mutual funds in 1995. The corresponding percentage was $7.1 \%$ in 2002 .
} 


\section{References}

Allen, F., Michaely, R., 2004. Payout policy. In: Constantinides, G., Harris, M., Stulz, R., (Eds.), Handbook of Economics. North Holland, Amsterdam.

Baker, M., Coval, J., Stein, J.C., 2004. Corporate financing decisions when investors take the path of least resistance. NBER Working paper 10998.

Barber, B., Odean, T., 2001. Boys will be boys: gender, overconfidence, and common stock investment. Quarterly Journal of Economics 116, 261-292.

Benartzi, S., Thaler, R.H., 2004. Save more tomorrow ${ }^{\text {TM}}$ : using behavioral economics to increase employee saving. Journal of Political Economy 112, S164-S187.

Bernheim, B.D., Skinner, J., Weinberg, S., 2001. What accounts for the variation in retirement wealth among U.S. households? American Economic Review 91, 832-857.

Blouin, J., Cloyd, B., 2005. Price pressure from dividend reinvestment activity: evidence from closed end funds. Unpublished working paper, University of Pennsylvania.

Browning, M., Lusardi, A., 1996. Household saving: micro theories and micro facts. Journal of Economic Literature 34, 1797-1855.

Grinblatt, M., Keloharju, M., 2000. The investment behavior and performance of various investor types: a study of Finland's unique data set. Journal of Financial Economics 55, 43-67.

Grinblatt, M., Keloharju, M., 2001. What makes investors trade? Journal of Finance 56, 589-616.

Grinblatt, M., Keloharju, M., 2004. Tax-loss trading and wash sales. Journal of Financial Economics 71, 51-76.

Gross, D.B., Souleles, N.S., 2002. Do liquidity constraints and interest rates matter for consumer behavior? Evidence from credit card data. Quarterly Journal of Economics 117, 149-185.

Grullon, G. Ikenberry, D., 2000. What do we know about stock repurchases? Journal of Applied Corporate Finance 13, 31-51.

Grullon, G., Michaely, R., 2002. Dividends, share repurchases and the substitution hypothesis. Journal of Finance 62, 1649-1684.

Haigh, M.S., List, J.A., 2005. Do professional traders exhibit myopic loss-aversion? An experimental analysis. Journal of Finance 60, 523-534.

Hasbrouck, J., 1991. Measuring the information content of stock trades. Journal of Finance 46, 179-207.

Iivarinen, T., 2002. Payment systems and instruments. In: Koskenkylä, H. (Ed.), Finnish Financial Markets 2002. Bank of Finland Studies A:105.

Karhunen, J., 2002. Who accepts tender offers? Unpublished working paper, Helsinki School of Economics.

Kaustia, M., 2005. Mental accounting of stock market profits: the 'buy low sell high' heuristic. Unpublished working paper, Helsinki School of Economics.

Levin, L., 1998. Are assets fungible? Testing the behavioral theory of life-cycle savings. Journal of Economic Behavior and Organization 36, 59-83.

Modigliani, F., Brunberg R., 1954. Utility Analysis and the Consumption Function: An Interpretation of Cross-section Data, in Kenneth Kurihara (eds.), Post-Keynesian Economics, New Brunswick N.J. Rutgers University Press. 
Odean, T., 1998. Are investors reluctant to realize their losses? Journal of Finance 53, 17751798.

Ogden, J., 1994. A dividend payment effect in stock returns. Financial Review 29, 345-369.

Rantapuska, E., 2005. Ex-dividend day trading: who, how, and why? Unpublished working paper, Helsinki School of Economics.

Samuelson, W., Zeckhauser, R., 1988. Status quo bias in decision making. Journal of Risk and Uncertainty $1,7-59$.

Shefrin, H.M., Statman, M., 1984. Explaining investor preference for cash dividends. Journal of Financial Economics 13, 253-282.

Shefrin, H.M., Statman, M., 1985. The disposition effect to sell winners too early and ride losers too long. Journal of Finance 40, 777-790.

Shefrin, H.M., Thaler, R.H., 1988. The behavioral life-cycle hypothesis. Economic Inquiry 26, 609-643.

Thaler, R.H., 1990. Anomalies: saving, fungibility, and mental accounts. Journal of Economic Perspectives 4, 193-205.

Thaler, R.H., 1994. Psychology and savings policies. American Economic Review Papers and Proceedings 84, 186-192.

Thaler, R.H., 1999. Mental accounting matters. Journal of Behavioral Decision Making 12, 183206.

Thaler, R.H., Shefrin, H.M., 1981. An economic theory of self-control. Journal of Political Economy 89, 392-406. 